\title{
Metastatic Malignant Melanoma of The Stomach in an Oculocutaneous Albino Patient: First Case
}

\author{
Halil KAVGACI ${ }^{1}$, Bulent YILDIZ ${ }^{1}$, Mustafa KARAGULLE ${ }^{2}$, Evren FIDAN ${ }^{1}$, \\ Umit COBANOGLU ${ }^{3}$, Feyyaz OZDEMIR ${ }^{1}$, Akif CINEL ${ }^{4}$ \\ ${ }^{1}$ Karadeniz Technical University Faculty of Medicine, Department of Oncology \\ ${ }^{2}$ Karadeniz Technical University Faculty of Medicine, Department of Internal Medicine \\ ${ }^{3}$ Karadeniz Technical University Faculty of Medicine, Department of Pathology \\ ${ }^{4}$ Karadeniz Technical University Faculty of Medicine, Department of Surgery, Trabzon, TURKEY
}

\begin{abstract}
Malignant melanoma is very rare in the case of oculocutaneous albinism and approximately thirty cases have been reported in the literature. Sixty year old male patient with oculocutaneous albinism was operated four years ago at the right leg due to amelanotic malignant melanoma. The patient taken under follow-up postoperatively, presented with upper gastrointestinal system bleeding. Endoscopic biopsy was reported as malignant melanoma metastasis and than total gastrectomy was performed. There is yet no case with gastric metastasis presenting with oculocutaneous albinism and amelanotic malignant melanoma in the literature. The clinical aspects of this unique case are presented.
\end{abstract}

Keywords: Melanoma, Oculocutaneous, Albinism, Stomach, Metastasis

ÖZET

Okülokutanöz Albinizmli Bir Hastada Mideye Metastatik Malign Melanom: Illk Vaka

Malign melanom okülokutanöz albinizimli hastalarda son derece nadir görülmekte olup literatürde yaklaşık 30 vaka bildirilmiştir. Okülokutanöz albinizimli 60 yaşındaki erkek hasta 4 yıl önce amelanotik malign melanom nedeniyle sağ bacağından opere edildi. Postoperatif izleme alınan hasta üst gastrointestinal sistem kanaması ile başvurdu. Endoskopisinde midede kitle saptanan hastanın alınan biyopsi sonucu malign melanom metastazı olarak rapor edildi ve total gastrektomi operasyonu uygulandı. Literatürde henüz oculocutaneous albinism ve amelanotik malign melanom birlikteliği ile seyreden mide metastaz॥ herhangi bir olgu olmayıp vakamız bu yönüyle ilk hasta olma özelliği taşımaktadır.

Anahtar Kelimeler: Melanoma, Okülokutanöz, Albinizim, Mide, Metastaz 


\section{INTRODUCTION}

Although malignant melanoma is a rare type of the skin cancers, it has the worst prognosis. Melanoma is responsible for $1 \%$ of all cancer related deaths. The most important factor in the development of melanoma is the UV light. Blond people with blue eyes are more sensitive to harmful effects of sun light and more prone to skin burns. However, while the most frequent skin cancer in amelanotic people are squamous and basal cell carcinoma respectively, malignant melanoma could be detected rarely.' Only 5\% of malignant melanoma patients are amelanotic. ${ }^{2}$ Oculocutaneous albinism is an autosomal resessive disorder characterized by general loss of pigmentation, nistagmus, photofobia and decrease in sight. ${ }^{3}$

\section{CASE REPORT}

Sixty year old male patient with oculocutaneous albinism admitted to our hospital with a mass at the right foot in 2004. The excisional biopsy result of the mass was reported to be amelanotic malignant melanoma (Clark Level III). The patient without metastasis was taken for follow-up without treatment. Three years later he admitted to our clinics with complaints such as fatigue, abdominal pain, weight loss and hematemesis. At the physical examination general loss of pigmentation, blue eyes, strabismus, nistagmus, decrease in sight, paleness

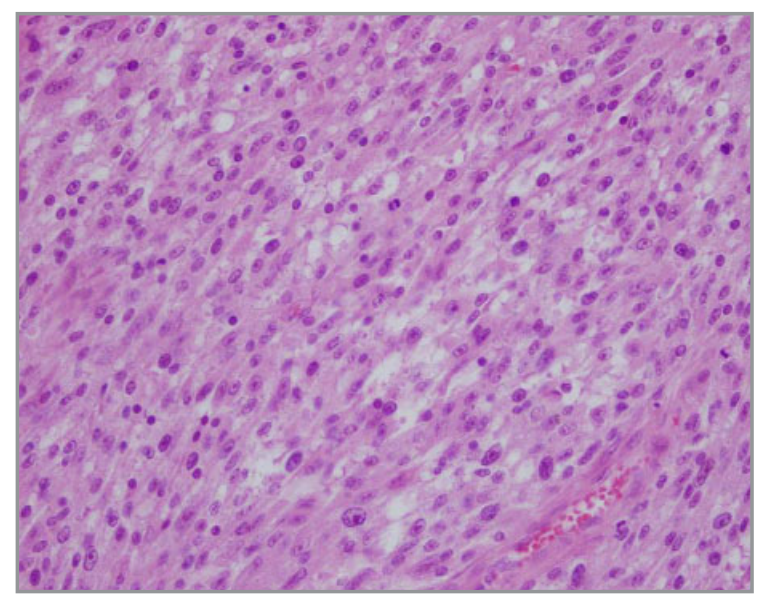

Figure 1. Neoplasm forming with spindle cells in stomach. (Hematoxylin-eosin; original magnification X 200). in conjunctiva and melena in rectal examination, were determined. A mass was determined at the gastric corpus in upper gastrointestinal system endoscopy and biopsy was taken. Pathology result was reported as in accordance with malignant melanoma metastasis. Total gastrectomy operation was performed because of recurrent persistent gastrointestinal bleeding. During the operation three seperate metastatic foci were determined at the gastric corpus, one of which exceeded the wall. Malignant melanoma metastasis was noted at six perigastric lymph nodes. In pathological examination, spindle cells was detected with hematoxylin - eosin (Figure 1), and S-100 (Figure 2) and HMB-45 (Figure 3) positivity were also detected with immunohistochemical staining. Postoperative chemotherapy with temazolamide $\left(200 \mathrm{mg} / \mathrm{m}^{2} / 1-5\right.$ days once 28 days) was initiated for the patient. The patient died because of progression of dissease after two cycles chemotherapy.

\section{DISCUSSION}

In malignant melanoma while the number of melanocytes are normal, there is a defect in the production of melanin. They generally metastase to skin, subcutaneous tissue and lymp nodes. The most frequent sites of visseral metastasis are lung, brain, liver, gastrointestinal system and bone.

While patients with cutaneous melanoma have a

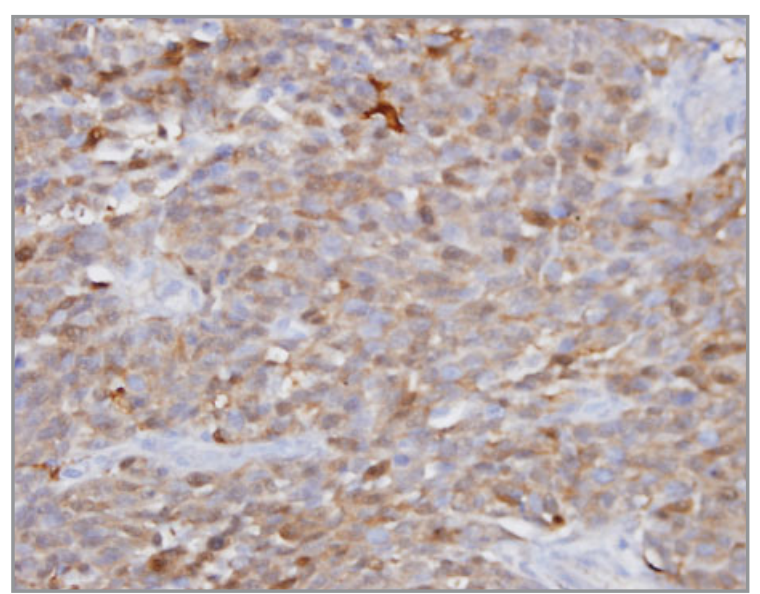

Figure 2. Positive immunohistochemical staining for S-100 expression in gastric metastasis of melanoma (Original magnification $X 400$ ). 


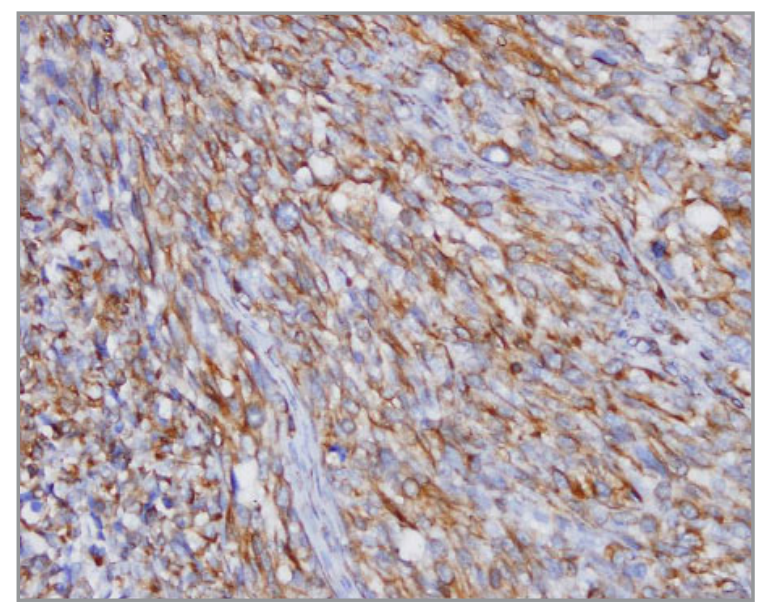

Figure 3. Positive immunohistochemical staining for HMB45 in gastric metastasis of melanoma (Original magnification $\mathrm{X}$ 400).

$4 \%$ incidence of gastrointestinal system metastasis when they are alive, this increases to over $60 \%$ in autopsy series. ${ }^{4}$ In studies on gastrointestinal system, metastasis was observed to small intestine, colon and stomach at percentages of $35-70 \%, 14.5$ $2.2 \%$ and $7-20 \%$ respectively. 5.6

Gastrointestinal system melanoma could be detected primarily or metastatically. One of the hypothesis for the development of gastric melanoma is the development from ectopic melanocytes at the gastric wall as a result of the migration of melanocytes to gastrointestinal system during embryogenesis.? However; gastric melanoma is a metastasis of cutaneous melanoma according to some authors. Primary skin melanoma is either missed during examination or the primary lesion spontaneously regresses. ${ }^{8}$ The determination of gastrointestinal system metastasis in over $60 \%$ of cutaneous melanoma cases at autopsy series, supports this hypothesis. Thus, we evaluated gastric involvement as metastasis due to the presence of cutaneous melanoma history and determination of multiple gastric metastasis in our patient.

Symptoms developed due to gastric metastasis of melanomas include abdominal pain, loss of weight, anemia and bleeding same as other gastric tumors. ${ }^{7}$ The presentation of our patient was in accordance with these symptoms.
Although there is not a full consensus for the treatment of metastatic melanoma, treatment alternatives include surgery, radiotherapy, chemotherapy, immunotherapy and combination of these treatments. It was shown in various studies that curative or palliative surgery increased survival in the involvement of gastrointestinal system. ${ }^{9}$

At the metastatic level; dacarbazine, temazolamide, IL-2, paclitaxel or combinations are recent treatment alternatives. We chose temazolamide treatment in our patient as it could be used orally, had a tolerable side effect profile and similar treatment response.

As a conclusion; the prognosis of malignant melanoma patients is stil not at the desired level despite the improvements at surgical and medical treatments together with early diagnostic methods.

There is yet no case with gastric metastasis presenting with oculocutaneous albinism and amelanotic malignant melanoma in the literature. The clinical aspects of this unique case are presented.

\section{REFERENCES}

1. Ozdemir N, Cangir AK, Kutlay H, Yavuzer ST. Primary malignant melanoma of the lung in oculocutaneous albino patient. Eur J Cardiothorac Surg 20: 864-867, 2001.

2. Koch SE, Lange JR. Amelanotic melanoma: the great masquerader. J Am Acad Dermatol 42: 731-734, 2000.

3. Cotran RS, Kumar V, Robbins SL. Genetic disorders. In: Robbins pathologic basis of disease. Cotran RS, Kumar V, Robbins SL (eds). Philadelphia, W.B. Saunders Company, 1989: 121-162.

4. Patel JK, Didolkar MS, Pickren JW, Moore RH. Metastatic pattern of malignant melanoma. A study of 216 autopsy cases. Am J Surg 135: 807-810, 1978.

5. Reintgen DS, Thompson W, Garbutt J, Seigler HF. Radiologic, endoscopic, and surgical considerations of melanoma metastatic to the gastrointestinal tract. Surgery 95: 635-639, 1984.

6. Dasgupta TK, Brasfield RD. Metastatic melanoama of the gastrointestinal tract. Arch Surg 88: 969-973, 1964. 
7. Dabrowski A, Zinkiewicz K, Szumilo J, et al. Unusual clinical course of metachronous melanomas of the upper digestive system. World J Gastroenterol 11: 2197 2199, 2005.

8. Lopez R, Holyoke ED, Moore RH, Karakousis CP. Malignant melanoma with unknown primary site. J Surg Oncol 19: 151-154, 1982.

9. Gallino G, Belli F, Bonfanti G, et al. Surgical treatment of gastric metastases from cutaneous melanoma: Experience of the National Cancer Institute of Milan. Tumori 87: 229-231, 2001.

\section{Correspondance}

Dr. Bülent YILDIZ

Karadeniz Teknik Üniversitesi Tıp Fakültesi

Medikal Onkoloji Bölümü

61080 Trabzon / TURKEY

Tel: (+90.0462) 3775023

Fax: (+90.0462) 32500518

E-mail: drbulentyildiz@hotmail.com 